\title{
Paternalistic leadership in Kuwaiti business environment: Culturally endorsed, but largely ineffective
}

\author{
Article history: \\ Received: 21 February 2021 \\ Sent for revision: 11 March 2021 \\ Received in revised form: 14 March 2021 \\ Accepted: 17 March 2021 \\ Available online: 30 April 2021
}

\begin{abstract}
There is an assumption from the reviewed literature that Paternalistic Leadership (PL) is culturally endorsed as a leadership style in Kuwait. With many diverse perspectives on the effectiveness of paternalistic leadership, the research objectives of the current research are threefold. First, to examine if PL is recognized as a leadership style in Kuwait organizations, second, to test the effectiveness of that style if present, and third, to identify the specifics of the Kuwaiti leadership practice. The findings lead to the conclusion that PL is present in Kuwaiti leadership practices, culturally is endorsed, but otherwise is considered as an ineffective leadership style because of the influence of wasta.
\end{abstract}

Keywords: Paternalistic Leadership, Kuwait, Culture, Leadership, Wasta.

\section{Paternalističko liderstvo u poslovnom okruženju Kuvajta: kulturološki prihvaćeno, ali pretežno neefikasno}

Apstrakt: Dostupna literatura vodi nas ka pretpostavci da je paternalističko liderstvo (PL) kulturološki prihvaćeno kao stil liderstva u Kuvajtu. Uzimajući u obzir različite poglede o efikasnosti paternalističkog liderstva, istraživački ciljevi našeg rada su trostruki. Prvo, da se ispita da li je paternalističko liderstvo prepoznato kao stil liderstva u kuvajtskim organizacijama; drugo, da se testira efikasnost PL stila ukoliko je prisutan; i treće, da se identifikuju specifičnosti kuvajtske rukovodne prakse. Rezultati nas dovode do zaključka da je PL

\footnotetext{
${ }^{1}$ Faculty of management FAM, University Union - Nikola Tesla, s.adzic@famns.edu.rs

${ }^{2}$ College of Business, American University of Kuwait, salmutairi@auk.edu.kw
} 
prisutan u kuvajtskoj rukovodnoj praksi, da je kulturološki prihvaćen, ali i da je prepoznat kao neefektivni stil liderstva zbog uticaja klijentilizma (vaste).

Ključne reči: paternalističko liderstvo, Kuvajt, kultura, liderstvo, klijentilizam.

\section{Introduction}

There are many diverse perspectives on paternalistic leadership and given the opposing findings within management literature (Aycan, 2006; Aycan et al., 2013; Mansur et al., 2017, 2017; Northouse, 2018; Pellegrini \& Scandura, 2008; Uhl-Bien \& Maslyn, 2005) with regard to the effectiveness of paternalistic leadership, more empirical work is necessary to assess the current state of the literature. Scholars (Dorfman et al., 2012; Kabasakal et al., 2012; Pellegrini \& Scandura, 2008) have argued that paternalistic leadership (PL) research is still relatively limited in scope and needs further future empirical research in order to provide consistent findings. Moreover, there is still very little empirical research on the Middle East, despite the abundant theoretical work. However, there is a suggestion from the reviewed literature (Adžić, 2015; Aycan et al., 2000; Badawy, 1980; Farh \& Cheng, 2000; House et al., 2004; Kabasakal et al., 2012; Kabasakal \& Bodur, 1998, 2002; Kuzulugil, 2009) that paternalistic leadership is culturally endorsed as a leadership style in Kuwait. With many diverse perspectives on the effectiveness of paternalistic leadership, the research objectives of the current research are threefold. First, to examine if PL is recognized as a leadership style in Kuwait organizations, second to test the effectiveness of that style if present, and third to identify the specifics of the Kuwaiti leadership practice. As such, the authors provide a review of the emerging body of literature on paternalistic leadership in the literature section and identify agreement and disagreements within. The authors also present further explanation of the methodology and discussion of the findings followed by the conclusion and recommendation for future research.

\section{Literature Review}

Paternalistic leadership is still a growing research area in leadership literature, and as such, there is still some disparity with respect to the definition of paternalism and how it relates to leadership. For example, studies emerging from Asia have suggested that paternalistic managers are protective and supportive of their subordinates (Redding et al., 1994). It is believed that paternalistic leadership is a style that combines strong discipline and authority with fatherly benevolence (Farh \& Cheng, 2000). Subordinates are expected to be loyal and comply with the paternalistic leader's instructions (Aycan et al., 
2013). Therefore, a paternalistic leader should provide support, protection, and care for their subordinates (Tang \& Naumann, 2015). Other studies have found paternalistic leadership to positively affect employees' attitudes in the work place (Aycan et al., 2013; Farh \& Cheng, 2000). However, the relationship is considered an exchange relationship such that the paternalistic leader provides care, nurturance, and guidance to employees in exchange for their loyalty and deference (Aycan et al., 2013).

Weber (1947) argued that paternalistic leaders inspire obedience in subordinates only because of his or her status. Traditional paternal authority is similar to the patriarchal household, in which the father expects obedience from the household in exchange for his care and protection (Weber, 1947). Moreover, there is substantial disagreement within the literature regarding the extent to which benevolent acts by paternalistic leaders are actually conducted genuinely and with no ulterior motive (Aycan, 2006). As such, it is perceived in a negative light in western literature (Pellegrini \& Scandura, 2008). Northouse (2018) defined PL as a benevolent dictatorship. Uhl-Bien and Maslyn (2005) argued that the benevolent aspects of a paternal leader are only demonstrated so that leaders receive something in return from their subordinates, such as obedience or indebtedness. PL is mainly criticized for its power inequality between the leader and his or her subordinates and was seen as more authoritarian than benevolent (Aycan, 2006; Uhl-Bien \& Maslyn, 2005).

Pellegrini and Scandura (2008) argued that paternalist leadership research is still relatively limited in scope and needs further future empirical research in order to provide consistent findings. Outside of the West, research on PL is flourishing, but the diversity of perspectives has resulted in conceptual ambiguities and contradictory empirical findings. The diversity of perspectives imply that empirical research is not abundant enough and that the PL theory itself has insufficient construct clarity (Pellegrini \& Scandura, 2008). Moreover, Mansur et al. (2017) argued that paternalistic leadership is not homogenous and that several types of paternalistic leadership styles are visible across cultures.

Dorfman et al. (2012) believed that there are some leadership qualities that are desirable in some cultures but undesirable in others. It is argued that national culture has a great effect on which culturally contingent leadership qualities are most likely to be desirable. National culture does not predict leadership behavior but can be used as an antecedent factor that can be used to influence leadership expectations. National culture is the framework within which the organizational culture develops (Adžić, 2017).

Despite its negative connotations in western literature, paternalistic leadership was perceived much more favorably in the Middle East and Asia and has reported higher paternalistic practices in its employees than western societies 
(Aycan et al., 2000; Farh \& Cheng, 2000). In particular, paternalistic leaders are more effective in high power distance and collective societies, where the involvement of the paternalistic leader is expected in collective societies and also has the right to expect favors from them, which is also accepted in power distance cultures (Pellegrini \& Scandura, 2008). PL, endorsed in high power distance and low collective cultures, is an emerging non-western theory (Mansur et al., 2017). Although Pellegrini and Scandura (2008) suggested, after presenting the empirical evidences from China, Pakistan, India, Turkey, Mexico, Japan, and Malaysia that PL is prevalent style in Asian, Middle-Eastern and Latin American cultures, Bauer (2015) found PL as successful behavior in Slovak organizations' environment. Benevolent paternalistic team leader is a formula for the effective Eastern European leader (Bauer, 2015). The root of the non-western academic stream of research lies in the findings of the Global Leadership and Organizational Behavior Effectiveness (GLOBE) Project (House et al., 2004), which advocated that effective leadership style is culturally endorsed.

The GLOBE project is a study conducted by House et al. (2004) during the period 1994-1997. The GLOBE study analyzed data from managers in different societies, including the Middle East, to understand the dominant values and leader attributes adopted by the respective cultures. The Middle Eastern cluster rated high on collectivism and high power distance, low on future orientation and gender egalitarianism, and scored mid-range on uncertainty avoidance, humane orientation, performance orientation, and assertiveness (House et al., 1999). The GLOBE project also identified six different leadership attributes that are perceived to be effective in different societies: autonomous, charismatic, humane, self-protective, participative, and team oriented. House at al. (1999) found that among the different types of leadership styles, the team oriented and charismatic were the most effective styles in the Middle East region. House et al. (2010) believed that there is a strong convergence in cultural values from the MENA (Middle East North Africa) countries in their GLOBE data which included Kuwait, Iran, Turkey, Qatar, Egypt, and Morocco. The countries all share high power distance and in group collectivism practices. In MENA countries leaders are expected to be powerful, hence paternalism is a leadership style that seems to fit their culture best (Kabasakal et al., 2012). An effective paternalistic leader creates a family-like atmosphere in the organization. Other researchers have suggested that people in MENA countries regard paternalistic leadership positively and display loyalty to their leaders (Aycan et al., 2000; Kuzulugil, 2009). Deeply seated societal norms and values emboss strictures and pressure on leaders with regard to the expectations of their subordinates and what is expected of them in terms of performance. PL is not an "ideal" style; autonomous and independent subordinates may be likely to reject paternalism (Redding, 1990). 
$\mathrm{PL}$ is perceived much more favorably in the Middle East and Asia and has reported higher paternalistic practices in its employees than western societies (Aycan, 2006; Farh \& Cheng, 2000). For example, Dorfman et al. (2012) found that top management leaders tend to behave in accordance with society's expectations of their leaders. Thus, if possible is to understand what type of leadership qualities that culture endorses then is possible to predict common behavior patterns of leaders within that culture group. Moreover, if the leader's behavior is congruent with their culture then their perceived effectiveness will also be increased. Badawy (1980) confirmed that Arab managers adopted managerial approaches that were congruent with their societal values but that also practiced western practices that are necessary for success globally. Leadership in the Arab cluster is paradoxical with lots of contradictory traits and the Arab societies continue to experience the duality of east and west, such that they retain a moderate set of leadership qualities that conform to their collective aspects while exhibiting a need for distinction and achievement because of the western influence. As such, the paternalistic leader often faces difficulty in being objective when following western HR practices for his or her subordinates while also preserving the close father like relationship expected from the PL managerial leadership type (Kabasakal \& Bodur, 2002). Hence, not all western practices are accepted and followed in Arab societies, such as a subordinate's evaluation of their manager's performance in a 360-evaluation scheme. Also, Kabasakal and Bodur (1998) argued that consultation is viewed favorably in Arab societies, in which subordinates feel like they are part of a family unit. However, even though Arab leaders consult their subordinates, the final decision always belongs to them as otherwise it would be seen as a sign of weakness (Adžić, 2015).

The MENA region embodies societal values that favor group orientation, masculinity, tolerance of ambiguity, and hierarchy of relationships (Kabasakal \& Bodur, 2002). In paternalistic leadership, all the ideas and strategies emanate from the leader and every process is centralized. Personal relationships are also very important in which close subordinates to the leader enjoy certain privileges and can also act as advisers and confidants to the leader (Kabasakal \& Bodur, 2002). The Middle East countries share the same cultural values such as large power distance and low individualism, which is the ideal setting for PL. It can be assumed that Kuwaiti culture, as any other culture, will define its own authentic leadership approach based on its values and local practices (Ertenu Saracer et al., 2012). Dorfman et al. (2012) argued that the MENA region needs more empirical studies with regard to culture and leadership and that much more understanding is necessary to understand the region. The MENA region is the least known region with regard to leadership styles as compared to the rest of the world (Kabasakal et al., 2012). 


\subsection{The Wasta effect}

It is argued that paternalistic leadership can lead to nepotism which may lead to inefficiency and corruption (Kabasakal \& Bodur, 2002). Hence, in the Middle East, nepotism is very common, in which personal relationships are enough incentive to produce work for others. A dynamic that might be relevant for understanding leadership interactions is favoritism (Palermo et al., 2018), known as wasta, a widely practiced method throughout the Arab world. Today, wasta is also known as vitamin W among Arabs, a synonym for corruption since people generally speak of wasta in negative terms and think largely of its corrupt side effects (Hutchings \& Weir, 2006). In the Arab world, social ties and relations are very important, in which the tribe and family play a significant role in facilitating the success of their relations, and in which wasta is seen as the facilitator.

Traditionally, wasta has been present in (tribal) Middle East for mainly mediation purposes (Talib, 2017), but over time has evolved and the objective has changed from defusing tribal conflicts to acquiring economic wealth. The use of wasta is considered to play a significant role in many decisions in the Arab world (Whiteoak et al., 2006). Wasta may refer to nepotism and social capital simultaneously, such that some Arabs lament the prevalence of wasta but also practice it themselves when the opportunity arises.

Wasta is a fixture of everyday life and it has become a right and expectation in Middle Eastern Arab societies (Talib, 2017). It is also seen that the younger generation is not as averse to wasta as previously hypothesized, in that they have grown used to the wasta effect and ultimately use it themselves for fear of being disadvantaged by the wasta of others (Whiteoak et al., 2006). Moreover, Hofstede (1983) referred to the Arab's love for wasta indirectly when he ranked the Arab culture as very high in power distance and very collective (Almutairi et al., 2018). The Arab State's high power distance ranking refers to the prevalence of inequality in the culture and how much it is endorsed by the members of its society, while their ranking as highly collective refers to their preference to work in groups and think in terms of "we". Emphasis from a collective to an individual benefit seems to be a relatively modern innovation in the wasta system and the current epidemic level of wasta, a previously benevolent system, has turned into something that is sinister and ugly (Talib, 2017). Wasta can also be seen as anti-meritocracy, such that the marginalization of the individuals not connected (or in the know) can be permanently blocked from entry to otherwise open opportunities and resources. Talib (2017) argued that present leaders in the Middle East are themselves mainly a product of the wasta system and are pro wasta oriented.

The Arab States have also scored highly on Hofstede's uncertainty avoidant index, which refers to their need to minimize as much ambiguity as possible. In 
fact, the adoption of such a managerial style may decrease the risk of dealing with the unknown since paternalistic leaders may appoint and favor subordinates who are closer to them and as such wasta is believed to be an integral feature of paternalistic leadership (O'Sullivan, 2016). Therefore, paternalism is seen as the most practiced of managerial styles in the Arab world, since it is concerned with maintaining close relationships between subordinates and their leader.

\subsection{Kuwait's profile within the MENA region context}

Geography wise, Kuwait is located in the Middle East. Kuwait is considered part of the Gulf countries, which include Qatar, Bahrain, Oman, Kingdom of Saudi Arabia, and United Arab Emirates are classified as high-income developing countries compared to other MENA countries. For example, $46 \%$ of the MENA region's 2.8 trillion dollars GDP is derived from the Gulf countries alone (The World Bank, 2016). High income is mainly result of the oil reserves of the Gulf countries, which grant them higher living standards than their neighboring Arab countries (Almutairi \& Yen, 2017).

In the Gulf region particularly, the ruling families dominate politics and the oil dominates their economies (Herb, 2009). The statement is especially true in Kuwait, as the overreliance on oil reserves has led to a distinct lack of diversification. With the oil prices fluctuating and caught in a downward spiral, Kuwait's national GDP has suffered tremendously. For example, Kuwait's 2017 GDP per capita fell from KD 31,124 to 27,996 KD as of late 2019 (Arab Times, 2019). Kuwait's predicament was foretold by Porter (1990) who argued that national prosperity is created and not inherited, a notion that is not quite understood in Kuwait. Additionally, the IMF (2018) does not rank Kuwait as a developed country despite the country having one of the highest GDP per capita in the world. Hajjieh (2011) explained that multiple factors have accounted for Kuwait's IMF ranking, such as the government's overreliance on oil as the only ultimate national income generator, the private sector's reliance on the government to make profits, and finally, on the influence of wasta in both the government and private sectors.

Recently, Kuwait has promised to diversify its economy and move away from depending heavily on its oil reserves in order to stimulate economic growth and development (Al-Kawaz, 2008). In order to do so, the government is trying to motivate the public to work in the private sector, and lessen the number of Kuwaitis working in the government, which stands at an alarming $74 \%$ (CIA, 2019). The recent ambitious plan aims to develop huge infrastructure projects and establish the country as a top regional commercial and financial hub by 2035 (Helmy, 2011). However, Kuwait's currently unstable political regime, its 
government's well documented corruption and lack of economic transparency made its plan to diversify less likely.

\section{Methodology}

There was an assumption from the reviewed literature (Adžić, 2015; Aycan et al., 2000; Badawy, 1980; Farh \& Cheng, 2000; House et al., 2004; Kabasakal et al., 2012; Kabasakal \& Bodur, 1998, 2002; Kuzulugil, 2009) that Paternalistic Leadership (PL) is culturally endorsed as a leadership style in Kuwait. With many diverse perspectives on the effectiveness of paternalistic leadership, the research objectives of the research are threefold. First, to examine if $P L$ is recognized as a leadership style in Kuwait organizations, second to test the effectiveness of the PL style if present, and third to identify the specifics of the Kuwaiti leadership practice.

The adopted research philosophy is centered on critical realism (Adžić, 2012), in order to discover and critically examine the leadership practices prevalent in the Kuwaiti setting. Hence, the paper will apply qualitative methods (EasterbySmith et al., 2018) by means of semi-structured interviews (Jankowicz, 2004). The research is an exploratory one and it will assume an inductive approach per se. However, in the stages of summarizing, categorization, and structuring of meanings, an iterative approach will be inevitable since new ideas will emerge from the data and the findings will be revised as more data is collected (McGivern, 2008). Consequently, the research strategy will be influenced by Grounded Theory (Glaser \& Strauss, 1967), especially in a context of identifying the specifics of the Kuwaiti leadership practice.

In order to discover not just the potential presence of PL in Kuwait, but also the effectiveness and uniqueness of the PL style in Kuwait, two groups of respondents were chosen. One cluster of interviewees was in top managerial positions to represent the leaders in the study. The aim was to recognize the presence of PL. The second cluster consisted of subordinates, with the aim to test the effectiveness of PL in Kuwaiti settings. Respondents were chosen based on non-probability sampling, which is a common sampling method chosen for qualitative research (Cohen et al., 2017). The non-probability sampling is selected as the optimal, since the Kuwaiti respondents who have relevant knowledge and professional roles in a managerial context are chosen. Interviews were conducted in February and March 2019.

Some obstacles were faced when conducting the interviews such as language, willingness to participate in an academic interview, and the most challenging difficulty which was the Kuwaiti's fluid understanding of time, which caused a large number of interviews to be rescheduled at short notice. However, the goal of conducting the ten interviews, five with leaders and five with subordinates, is 50 
achieved within a two-month period. Theoretical saturation (Glaser \& Strauss, 1967) indicated that ten interviews were sufficient. The small number of participants may lead to the findings being less generalizable; however, the strength of the findings of the study is acquiring in-depth knowledge from relevant stakeholders to better inform and expand the small body of literature on PL styles in the Middle East.

Four men and one woman represented the study's leader cluster. The leaders were chosen from governmental and non-governmental sectors, coming from different education levels and experience and were mainly middle aged. Two women and three men represented the subordinates cluster. The subordinates were chosen on the same principle, representing both the private and public sector, with different experiences and education levels, and were mainly middle-aged, with an additional condition to work under a Kuwaiti leader. The interviews were recorded and transcribed for further analysis (Saunders et al., 2015). Through the data analysis processes and integration of interviews' findings from both groups of respondents, wasta emerged as a key theme for further exploration, as initially predicted. The findings generated the four leadership profiles unique to Kuwaiti settings and leadership practices, which will be elaborated on in the next section.

The leadership sample consisted of five participants, marked as L1-5. L1 and L2 have high positions at a not for profit university and both hold a Ph.D. degree. In particular, L2 has vast prior experience in the private sector as well as in the Army. L3 is the only female in the sample of leaders, a business diploma holder, and a manager of a bank branch in the private sector. L4 is also in the private sector as a manager in a big company; in addition, he is an entrepreneur with a business degree. Lastly, L5 holds a bachelor's degree in the arts and works in the public sector, as a manager in Kuwait's cultural center. In total, the study includes two leaders from the private sector and three representing the government sector.

The subordinates sample consisted of five participants, marked as S1-5. S1 is a business student who works as a quality and safety officer in a large private company in the aviation industry. S2 works for the government in the Ministry of Defense. S3 holds a Ph.D. and works as an assistant professor at the University. S4 is the first female in the subordinates group. She works as an officer in one of the largest banks in Kuwait. Lastly, S5 is the second female in the subordinates group; a business student who works in the private sector, specifically in the oil industry. All subordinates are not organizationally connected in any way with the leadership group, so as to avoid bias and conflict of interest. In total, the cluster consisted of three subordinates from the private sector and two in sectors regulated by the government. For the purpose of the research, the current leaders of the subordinates from the subordinate sample LS will be marked as LS1-5. 
The semi-structured interview consisted of twelve open ended questions. However, four main themes emerged as distinctive from analyzing the respondents' answers. In the leader cluster, the themes were: what they think of their leadership style and what they believe an ideal leadership style should be; what they think about the influence of culture on leadership practices in Kuwait; how they view the decision process and relationship with their subordinates; and what they think about wasta. In the subordinate cluster the themes were: how they view the leadership style of their leader and what they believe the ideal leadership style to be; what they think about the influence of culture on leadership practices in Kuwait; how they view the decision process and relationship with their leaders; and what they think about wasta. Each of the themes from the conducted interviews will be presented in Annex as the research output in detail.

\section{Discussion}

The aim of the research is to explore PL in a Kuwaiti setting. A paternalistic leader acts as a pater familias toward their subordinates, treating them as children. Accordingly, for one to be recognized as a paternalistic leader, he or she may (a) be solely in charge of the decision making process in the organization and may (b) develop strong social connections with their subordinates. A paternalistic leader is an autocrat. Therefore, for one to be recognized as a paternalistic leader, he or she may (c) have an autocratic style of leadership, albeit a benevolent one. Additionally, in order to be recognized as a more culturally endorsed leader, a paternalistic leader in Kuwait may (d) inherit a main cultural artefact called wasta, which was a very common theme emerging from the conducted interviews. As such, for the purpose of the research, for one to be recognized as a paternalistic leader in Kuwait, he or she should satisfy most of the stated conditions. It could be argued that LP is recognized as a leadership style in Kuwait if it could be verified that the majority of the sample have met at least three of the stipulated conditions.

A paternalistic leader treats their subordinates as children and because of the sense of immaturity that children naturally have, the paternalistic leader will inevitably be put in charge of decisions. It is confirmed from the interviews with the leader cluster, in which it is found that leaders would not allow their subordinates to participate in the decision process. Almost with indignation, the leaders refuse to discuss their decisions with their subordinates believing that it is not the way that Kuwaiti leaders act. It is found only one leader, L4, who was ready to be more democratic in making his decisions, such that he would invite his subordinates to comment on his decisions. However, he would revise the decision again and he would finalize it. Generally, the final say still belongs to him; however, he does allow his subordinates to feel included in the decision52 
making process, though with little power to influence the decision. Additionally, all subordinates explained the process of decision making in a similar way. Managers are in charge of making decisions, but not all subordinates are convinced that managers are the only ones who know what is best for the company. Therefore, it could be extracted the group of potential paternalistic leaders who meet the requirements of the first condition as L1, L2, L3, L5, LS1, LS2, LS3, LS4, and LS5.

Relationship with subordinates is very important for the majority of the leaders. All the leaders clearly stated that having contact with their subordinates is a "need". It may be seen as the influence of tribal affiliation, family name, and social connection. However, not all leaders prefer contact with their subordinates outside of work, as in the case of $L 5$ from the sample. It is also the case with the majority of subordinates' leaders; namely, only LS3 clearly stated that there is social contact after work. Nevertheless, terms like "brother" and "family" are in the vocabulary of both groups, but the difference in attitudes leads to the conclusion that tight connections in and outside of the company are not as prevalent in modern Kuwait. Consequently, it could be extracted the group of potential paternalistic leaders who meet the requirements of the second condition as L1, L2, L3, L4, and LS3.

The findings proved that an autocratic leadership style is very prevalent in the leaders' cluster. Only one leader, L4, is recognized as a semi-democratic, i.e. permissive one. The term "democratic" is not used since the term "semidemocratic" could emphasize not just the democratic style, but also a visionary one, a permissive one, or even a laissez-faire one. The autocratic leadership style is practiced among subordinates' leaders as well. LS2 is described as someone who is a fine example of a laissez-faire leader. Moreover, LS5 is not clearly stated as an autocratic leader but because of his gender sensitive treatment of the female workers, he could be considered as a semi-democratic one. However, not all subordinates look at their leader as a parent figure. One of the subordinates pictured his manager as a tyrant since fear was the main ingredient of their leader-subordinate relationship. Therefore, it could be extracted the group of potential paternalistic leaders who meet the requirements of the third condition as L1, L2, L3, L5, LS1, LS3, and LS4.

Wasta stand out almost immediately during the interviewing process as the most important factor influencing Kuwait's leadership practice. Any attempt at addressing the PL style in Kuwait without considering wasta would be incomplete. In Kuwait, wasta is "the main catalyst" and is used mostly as a synonym for corruption. However, some leaders, like L1 and L2, prefer wasta, such that they like to do favors in the name of the tribe, family, and name. For L1 and L2, wasta is an expected and culturally positive practice in Kuwait, because the tribe is the "essence". Still, the majority of leaders from the sample, like L3, L4, and L5, are not wasta supporters, especially the leaders from the 
private sector, which is inadvertently a sector that comprises of a substantially high number of expat workers. On the other hand, the negative connotations of wasta were gleaned more clearly from the answers of subordinates. All subordinates agreed that wasta is omnipresent and that it is harmful and has a negative cultural effect, such that it can be considered as the source of corruption in society. From the subordinates' sample, all the leaders of the subordinates except LS4 and LS5 could be marked as wasta preferred. Consequently, it could be extracted the group of potential paternalistic leaders who meet the requirements of the fourth condition as L1, L2, LS1, LS2, and LS3.

Finally, all the findings have been compiled in order to compare the leaders from the samples and the required PL conditions. As shown in Table 1, five of the ten leaders have the required conditions to be declared paternalistic leaders - L1, L2, L3, LS1, and LS3. Three of them - L1, L2, and LS3 - fulfilled the maximum number of the required four conditions. Therefore, it could be presupposed that the PL style is culturally endorsed and that it is represented and practiced in the management of modern Kuwait.

Table 1. Compiling of the conditions with leadership characteristics from the sample in order to generate PL results

\begin{tabular}{|l|l|l|l|l|l|l|l|l|l|l|l|}
\hline & L1 & L2 & L3 & L4 & L5 & LS1 & LS2 & LS3 & LS4 & LS5 & \\
\hline $\begin{array}{l}\text { a) Decision } \\
\text { maker }\end{array}$ & X & X & X & & X & X & X & X & X & X & \\
\hline $\begin{array}{l}\text { b) Socially } \\
\text { connected }\end{array}$ & X & X & X & X & & & & X & & & \\
\hline $\begin{array}{l}\text { c) Autocratic } \\
\text { style X }\end{array}$ & X & X & X & & X & X & & X & X & & \\
\hline $\begin{array}{l}\text { d) Wasta } \\
\text { inherited }\end{array}$ & X & X & & & & X & X & X & & & \\
\hline $\begin{array}{l}\text { All 4 } \\
\text { conditions }\end{array}$ & $\checkmark$ & $\checkmark$ & & & & & & $\checkmark$ & & & $\begin{array}{l}\text { Paternalistic } \\
\text { leadership }\end{array}$ \\
\hline $\begin{array}{l}\text { 3 of 4 } \\
\text { conditions }\end{array}$ & & & $\checkmark$ & & & $\checkmark$ & & & & & \\
\hline $\begin{array}{l}\text { Non- } \\
\text { paternalistic }\end{array}$ & & & & $\checkmark$ & $\checkmark$ & & $\checkmark$ & & $\checkmark$ & $\checkmark$ & \\
\hline
\end{tabular}

However, one question emerged after further analysis: is PL, as a culturally endorsed leadership style in Kuwait, also the most effective one? In order to answer the stated question, the next step would be to generate profiles of Kuwaiti leaders from the sample, with respect to the style of leading (autocratic vs. semi-democratic) and with respect to wasta influences. Compiling the findings in Fig. 1, four leadership profiles are recognized in Kuwait. As can be seen, every respondent in the research has been matched with the appropriate profile with no overlap. Moreover, all the quadrants in the model feature at least 54 
one leader from the sample which demonstrates the model's validity and robustness.

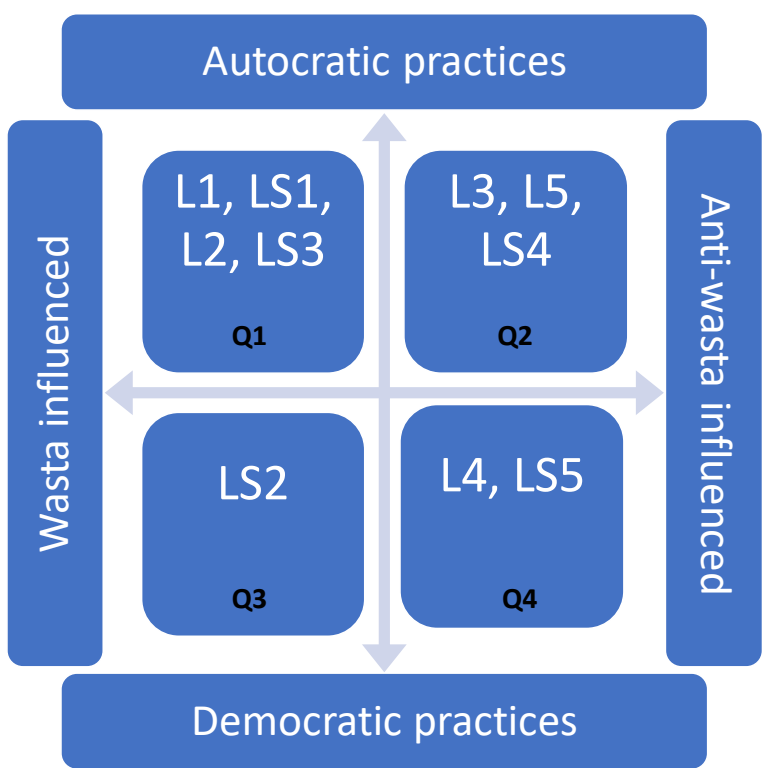

Figure 1. Profiles of the Kuwaiti leaders in the wasta system

In the top left corner, or Q1, is the autocratic leader who has no problem with wasta practices. It is the position where it could be found most of the leader sample: four of the ten leaders (of five interviewed and five mentioned by subordinates), i.e. L1, L2, LS1, and LS3. The profile could be seen as a leader who inherits cultural practices such that they view social contacts as very important. In the first quadrant, all four leaders are recognized as paternalistic leaders in the research.

In the top right corner, or Q2 of the model, is an autocratic leader who is not wasta oriented. Some of the leaders possess the paternalistic characteristics, such as L3, but the majority of the sample from that quadrant, i.e. L5, and LS4, do not. Most likely, leaders from the second quadrant will succeed in organizations with a high percentage of expat workers. That is actually quite usual in Kuwait where the nationals are the minority in their own country. However, it is questionable how that profile would act in organizations under the process of Kuwaitization, which is a new governmental initiative that 
stipulates that private sector organizations should hire a specific percentage of its workers from the Kuwaiti nationality.

In the bottom left corner, or Q3, is a leader who has no authority over his men. The third quadrant leader is influenced by wasta and most likely he was appointed to the position by wasta. An example of an incompetent public manager is LS2.

Lastly, in the bottom right corner, or Q4, is the position of a leader who treats the subordinates with respect, such that democratic principles are recognized and upheld. That leader would be not only gender sensitive but also a leader who recognizes the value of diversity and the harmful effects of wasta practices. The leaders in the fourth quadrant, i.e. L4 and LS5, are recognized as the most effective ones.

The Q1 profile is a fine example of a culturally endorsed leader, but that profile is not the desired one in times of change. Old patterns are not useful in times of change and new practices are inevitable. The Q2 profile could perhaps bring some new practices, but in a setting where Kuwaitis constitute the majority of the workforce, where new ways of thinking may not be culturally endorsed and recognized behavior. The future of Q2 leaders is not bright in the usual settings, but it will survive in organizations where expat workers are the majority. The Q3 profile is a leader whom subordinates do not trust and view suspiciously as it is common knowledge that he was only appointed because of his connections, or wasta. There is no efficacy; only chaos prevails in such organizations, which are under such a leader. Finally, Q4 is a profile of a modern leader who is not under the burden of the old ways and not affected by cultural practices. That is the agent of change and only that leader has the characteristics of a transformational leader. Therefore, it could be argued that the Q4 profile is the synonym for the most effective leadership practices in Kuwait. It is not the most practiced in Kuwait, but also it demonstrates that being a culturally endorsed style is not a guarantee of its effectiveness.

\section{Conclusion}

The aims of the research are to explore whether PL is present in Kuwait, to further reveal what specific Kuwaiti leadership practices are prevalent, and to finally address the effectiveness of the recognized leadership practices in Kuwait. Wasta influence on the leadership practice and processes is the most noteworthy exploration of the research. Findings clearly indicate the presence of PL, but subsequent analysis of findings revealed that it was not the most effective leadership style. The research evidences that a culturally endorsed leadership style is not unconditionally the most effective one, as the findings have indicated that another leadership profile is more effective in Kuwait than 56 
the paternalistic leadership profile, which is currently the leadership style that is most prevalent and recognized. Therefore, the advice is that the results of cultural studies in management science should be used with caution. Small sample size is the major obstacle of the current research. It could be recommended and expected that future research extends the number of sample size, so as to further test the robustness of the findings of the current research.

\section{References}

Adžić, S. (2012). The Impact of Critical Realism on the Management Research Procedures. In D. Ristić (Ed.), Methodology of the Business Research: A monograph (pp. 15-36). Fakultet za menadžment.

Adžić, S. (2015). Business Leadership Challenges in Saudi Arabia. 3rd Annual Seminar on "Improving Organizational Performance by Effective Leadership," University of Hafr Al-Batin, Saudi Arabia.

Adžić, S. (2017). Leadership in the High Performance Organizations. Lap Lambert Academic Publishing.

Al-Kawaz, A. (2008). Economic diversification: The case of Kuwait with reference to oil producing countries. Journal of Economic Cooperation Among Islamic Countries, 29(3).

Almutairi, S., \& Yen, D. (2017). International Diffusion of Digital Innovations: Mapping the Mobile Telephony of the Arab States. The Bottom Line, 30, 00-00. https://doi.org/10.1108/BL-08-2017-0020

Almutairi, S., Yen, D., \& Heller, M. (2018). The Many Facets of National Culture: A Critical Appraisal. Comparative Sociology, 17, 759-781. https://doi.org/10.1163/15691330-12341478

Arab Times. (2019, April 20). Kuwait's GDP trends 'downward.' ARAB TIMES - KUWAIT NEWS. http://www.arabtimesonline.com/news/kuwaits-gdp-trends-downward/

Aycan, Z. (2006). Paternalism. In U. Kim, K.-S. Yang, \& K.-K. Hwang (Eds.), Indigenous and Cultural Psychology: Understanding People in Context (pp. 445-466). Springer US. https://doi.org/10.1007/0-387-28662-4_20

Aycan, Z., Kanungo, R., Mendonca, M., Yu, K., Deller, J., Stahl, G., \& Kurshid, A. (2000). Impact of Culture on Human Resource Management Practices: A 10-Country Comparison. Applied Psychology, 49(1), 192-221. https://doi.org/10.1111/1464-0597.00010

Aycan, Z., Schyns, B., Sun, J.-M., Felfe, J., \& Saher, N. (2013). Convergence and divergence of paternalistic leadership: A cross-cultural investigation of prototypes. Journal of International Business Studies, 44(9), 962-969. https://doi.org/10.1057/jibs.2013.48

Badawy, M. K. (1980). Styles of Mideastern Managers. California Management Review, 22(3), 51-58. https://doi.org/10.2307/41164876

Bauer, D. (2015). Successful leadership behaviours in Slovak organizations' environment - an introduction to Slovak implicit leadership theories based on GLOBE study findings. Journal of East European Management Studies, 20(1), 9-35. https://doi.org/10.5771/0949-6181-2015-1-9 
CIA. (2019). The World Factbook-Central Intelligence Agency. https://www.cia.gov/library/publications/resources/the-world-factbook/

Cohen, L., Manion, L., \& Morrison, K. (2017). Research Methods in Education (8 edition). Routledge.

Dorfman, P., Javidan, M., Hanges, P., Dastmalchian, A., \& House, R. (2012). GLOBE: A twenty year journey into the intriguing world of culture and leadership. Journal of World Business, 47(4), 504-518. https://doi.org/10.1016/j.jwb.2012.01.004

Easterby-Smith, M., Thorpe, R., Jackson, P. R., \& Jaspersen, L. J. (2018). Management and Business Research (Sixth edition). SAGE Publications Ltd.

Ertenu Saracer, B., Karacay-Aydin, G., Asarkaya, Ç., \& Kabasakal, H. (2012). Linking the Worldly Mindset with an Authentic Leadership Approach: An Exploratory Study in a Middle Eastern Context. In S. Turnbull, P. Case, G. Edwards, D. Schedlitzki, \& P. Simpson (Eds.), Worldly Leadership: Alternative Wisdoms for a Complex World (pp. 206-222). Palgrave Macmillan UK. https://doi.org/10.1057/9780230361720_12

Farh, J.-L., \& Cheng, B.-S. (2000). A Cultural Analysis of Paternalistic Leadership in Chinese Organizations. In J. T. Li, A. S. Tsui, \& E. Weldon (Eds.), Management and Organizations in the Chinese Context (pp. 84-127). Palgrave Macmillan UK. https://doi.org/10.1057/9780230511590_5

Glaser, B. G., \& Strauss, A. L. (1967). The Discovery of Grounded Theory: Strategies for Qualitative Research. Aldine de Gruyter.

Hajjieh, A. (2011, April 20). Why has Kuwait failed to develop for the last 30 years? Quora. Quora. https://www.quora.com/Why-has-Kuwait-failed-to-develop-forthe-last-30-years

Helmy, M. A. (2011). Investigating the critical success factors for PPP projects in Kuwait. http://urn.kb.se/resolve?urn=urn:nbn:se:kth:diva-77471

Herb, M. (2009). A nation of bureaucrats: Political participation and economic diversification in Kuwait and the United Arab Emirates. International Journal of Middle East Studies, 41(3), 375-395. https://doi.org/10.1017/S0020743809091119

Hofstede, G. (1983). The Cultural Relativity of Organizational Practices and Theories. Journal of International Business Studies, 14(2), 75-89. https://doi.org/10.1057/palgrave.jibs.8490867

House, R. J., Hanges, P. J., Javidan, M., Dorfman, P. W., \& Gupta, V. (2004). Culture, Leadership, and Organizations: The GLOBE Study of 62 Societies. SAGE Publications.

House, R. J., Hanges, P. J., Ruiz-Quintanilla, S. A., Dorfman, P. W., \& Dickson, M. (1999). Cultural Influences on Leadership and Organizations: Project GLOBE.

House, R. J., Quigley, N. R., \& Luque, M. S. de. (2010). Insights from Project GLOBE. International Journal of Advertising, 29(1), 111-139. https://doi.org/10.2501/S0265048709201051

Hutchings, K., \& Weir, D. (2006). Guanxi and Wasta: A comparison. Thunderbird International Business Review, 48(1), 141-156. https://doi.org/10.1002/tie.20090

IMF. (2018, October). World Economic Outlook Database. https://www.imf.org/external/pubs/ft/weo/2018/02/weodata/weoselagr.aspx\#a 110 
Jankowicz, A. D. (2004). Business Research Projects (4th edition edition). Cengage Learning EMEA.

Kabasakal, H., \& Bodur, M. (1998). Leadership, values and Institutions: The Case of Turkey: Research Papers. Istanbul: Bogazici University. http://linkinghub.elsevier.com/retrieve/pii/S1090951601000736

Kabasakal, H., \& Bodur, M. (2002). Arabic cluster: A bridge between East and West. Journal of World Business, 37(1), 40-54. https://doi.org/10.1016/S10909516(01)00073-6

Kabasakal, H., Dastmalchian, A., Karacay, G., \& Bayraktar, S. (2012). Leadership and culture in the MENA region: An analysis of the GLOBE project. Journal of World Business, 47(4), 519-529. https://doi.org/10.1016/j.jwb.2012.01.005

Kuzulugil, S. (2009). Does One Size Fit All? Value-Based Subcultures and Leadership Preferences in Turkey. Bogazici.

Mansur, J., Sobral, F., \& Goldszmidt, R. (2017). Shades of paternalistic leadership across cultures. Journal of World Business, 52(5), 702-713. https://doi.org/10.1016/j.jwb.2017.06.003

McGivern, Y. (2008). The Practice of Market Research: An Introduction (3 edition). Financial Times/ Prentice Hall.

Northouse, P. G. (2018). Leadership: Theory and Practice (Eighth edition). SAGE Publications, Inc.

O'Sullivan, K. (2016). Paternalistic University Leadership in the UAE - Its Impact on Management Behaviour. International Review of Social Sciences and Humanities, 11, 54-64.

Palermo, O. A., Carnaz, A. C., \& Duarte, H. (2018). Favouritism: Exploring the 'uncontrolled' spaces of the leadership experience. Leadership, 1742715017749190. https://doi.org/10.1177/1742715017749190

Pellegrini, E. K., \& Scandura, T. A. (2008). Paternalistic Leadership: A Review and Agenda for Future Research. Journal of Management, 34(3), 566-593. https://doi.org/10.1177/0149206308316063

Porter, M. E. (1990). The Competitive Advantage of Nations. Harvard Business Review, March-April 1990. https://hbr.org/1990/03/the-competitive-advantage-ofnations

Redding, G. (1990). The Spirit of Chinese Capitalism. Walter de Gruyter.

Redding, G., Norman, A., \& Schlander, A. (1994). The nature of individual attachment to theory: A review of East Asian variations. In Handbook of industrial and organi-zational psychology (H. C. Triandis, M. D. Dunnett, L. M. Hough, pp. 674-688). Palo Alto, CA: Consulting Psychology Press.

Saunders, M. N. K., Lewis, P., \& Thornhill, A. (2015). Research Methods for Business Students. Pearson Education Limited.

Talib, A. A. (2017). Wasta: The Good, the Bad and the Ugly. Middle East Journal of Business, 12(2), 3-9. https://doi.org/10.5742/MEJB.2017.92942

Tang, C., \& Naumann, S. E. (2015). Paternalistic leadership, subordinate perceived leader-member exchange and organizational citizenship behavior. Journal of Management \& Organization, 21(3), 291-306. https://doi.org/10.1017/jmo.2014.84

The World Bank. (2016). World development indicators 2016 (No. 105051; pp. 1-180). The

World

Bank. 
http://documents.worldbank.org/curated/en/805371467990952829/Worlddevelopment-indicators-2016

Uhl-Bien, M., \& Maslyn, M. (2005, August). Paternalism as a form of leadership: Differentiating paternalism from leader-member exchange. Meeting of the Academy of Management, Honolulu, Hawaii.

Weber, M. (1947). The Theory Of Social And Economic Organization. The Free Press.

Whiteoak, J. W., Crawford, N. G., \& Mapstone, R. H. (2006). Impact of gender and generational differences in work values and attitudes in an Arab culture. Thunderbird International Business Review, 48(1), 77-91. https://doi.org/10.1002/tie.20086

\section{Annex: Research Output from Interviews}

How leaders view their own leadership style and what they believe an ideal leadership style should be

L1 believed that the following regulations were the most important aspect of any leader:

"I look at the regulations; try to delegate things to minimize stress."

Although L1 is delegating in order to avoid stress, the ideal leader for him is someone who can inspire people. L2 explains his style as a style different from other cultures because he is considering the tribe, the family, and the name when dealing with people:

"We rank people based on their background. It's not about discrimination. In managing people, you have to consider this."

An ideal style for him would be a more social and outgoing leader, one who considers having a social life as necessary, and who does not treat people like machines. L3, the only female leader, explained her style as someone who is focusing on achieving targets, and regarding subordinates, she states,

"I like to lead people; I like to be a friend, sister, family."

Her view is that the development of technology will improve leadership practices in Kuwait. L4's leadership style depends on the situation and the staff and their level of experience. His preferred leadership style is:

"You delegate the job but also, the same time, you have to watch."

For him, a directive permissive leadership style is best, but he also stated that Kuwaitis are usually autocratic:

"In meetings, you have to agree what is your boss saying, everybody, has to agree."

L5 believed that a leader should be friendly and should work with subordinates as if they are family, although he prefers to be more formal. Moreover, L5 believed that leading without the interference of wasta is the best leadership style in Kuwait: 
"Don't bring your people, family, tribe ... bring the qualified ones."

For him, the business atmosphere in the banking sector in Kuwait is the most effective.

What leaders think about the influence of culture on leadership practices in Kuwait

L1 stated, indicating towards Kuwait culture's high power distance ranking, that every manager is a leader here:

"The most important thing in the cultural understanding is a help. I mean favour."

On the other hand, the tribe proves to be the essence of cultural influences for L2. He sees the organization as a tribe and claims that Kuwaitis will do their best, for the company, as a tribe:

"I will consider the company as a tribe, as a social structure within the country. So this is the part of the country."

As the main cultural influence, L3 cites gender inequality in Kuwait as a reason for not being accepted to hold a managerial leader position for more than two years. However, even now, after five years as a manager, she is not recognized as a leader outside of her department among people from many backgrounds in Kuwait:

"They don't accept they have a (female) leader."

Moreover, tribal influence is the cultural influence that is of concern for $L 4$, which he stated is more prevalent in the government sector than in private companies. Additionally, L5 viewed wasta as the main cultural influence on leadership practices in Kuwait.

How leaders view the decision process and relationship with their subordinates

When participating in the top management decision process, L1 views himself as more of a listener:

"When I [make] a decision, I don't have to discuss [it] with anyone."

For L1, managers know what is best for the organization. Social contacts for him are important:

"Like disposition for someone to be always ready for others."

The same view regarding decisions was held by $L 2$ when he stated that the head of the company should be in charge of the decision, but not as a dictator. He stated that it has to be a discussion. Relationship with subordinates is very important, especially in Kuwait in which it is seen as very collective. Likewise, L3 sees a relationship with subordinates as a family one.

"I need to have contact. We are friends also outside, gathering, going out."

However, she stated that the decision is her and that subordinates are not included in the decision process. For L4, the decision process in private companies is based on written procedures; however, when it comes to imperative procedures, the company owner's decision should be taken into consideration. On his level of authority, it is different.

Industrija, Vol.49, No.1, 2021 
"Before making a decision I have to revise it, to be sure that my decision is the right one. I will give the staff a chance to come [up] with their position and to come [up] with their decision. I will revise [again]; I will say okay or no."

$\mathrm{L} 4$ also believes that the relationship with subordinates is very important:

"If you are very good in your job, but you don't have the relationship with your boss, he could appoint another one".

According to $L 4$, the staff, especially the ones on the front line, know what is best for the company. On the other hand, L5 supposes that the government should know what the best is, but because of wasta, they are not qualified. L5 also prefers not to have contact outside of the job with his subordinates. With regard to the decision process, he would sometimes ask his subordinates for advice, but most likely he and his assistant are those who would make decisions.

\section{What leaders think about wasta}

L1 believes that wasta is a culturally positive practice in Kuwait and has a positive influence on his leadership styles:

"If you can use all of that tradition to do things, it's very good and it's very complicated."

However, he stated that sometimes because of wasta he has to do things that he is not totally convinced about. Moreover, L1 sees wasta as a cultural practice and help system. He claims that all Kuwaitis do practise wasta. L1 also explained that wasta acted as the surrogate for the State in the old times before Kuwait's sovereignty:

"It's security. If I kill his daughter, I will think one hundred times if I want to do that. In the absence of state throughout history, the state was weak, but society was very strong. This is how it is, people need this."

L2 also views wasta favorably. He expects wasta since it is so prevalent, although he is aware that the overuse of wasta can create corruption. His attitude is that wasta, if used in balance, could be perfect for the organization:

"But people used it in a corrupt way, breaking all the rules and the system. Wasta will not corrupt the system and the rules; wasta will manage the system and the rule."

On the other hand, L3 admitted that wasta is very important in Kuwait, but not too much in the private sector and in banking. He complains that wasta is very present in the government sector. The negative view of wasta was also present in L4's viewpoint, in which he laments that wasta is affecting the performance of companies. He noticed the increase of wasta in the last three years:

"I don't know why. Now leaders ... all [are] trying to make people happy, more than caring to have a quality staff."

L4 also noticed pressure to hire incompetent family members for managerial positions, not the skilled expats managers as before. This particularly negative attitude towards wasta is also shared by L5. He claims that leadership is bad in Kuwait because of wasta. People are not hired based on qualification and experience:

62 
"Favour for favour. Goes on and on. Wasta is very bad. If you accept ones you are stacked, you have to pay. To say no you can't."

How subordinates view the leadership style of their leader and what they believe the ideal leadership style to be

S1 explained the style of his manager LS1 as a leader who employs the carrot and stick approach.

"No feedback if you do something good. Always pissed-off, always mad and yelling."

An ideal style for him would be to lead by example, which, he claims is hard to apply in Kuwait. Concurrently, S2 pessimistically stated that to work with Kuwaitis is hard and with a Kuwaiti manager, is even harder. S3 described his ideal leadership style as a democratic one, but he does not believe his superior LS3 to be behaving in a democratic manner:

"[They] act according to the law and the social norms to cover themselves".

S4 described the ideal leader as a person who is aware of everything; a person who will be of help to the subordinate, which is contrary to her present manager LS4. S5 described her current manager LS5 as a nice person who does not treat men different to women:

"He mostly treats women much nicer than men. My previous boss wasn't like this. That was very tiring. Whatever you do is not appreciated because you are female."

To her, an ideal leader is a gender-sensitive person who appreciates work and effort; someone who inspires motivation to work more and to be a better person.

How subordinates see cultural influences on leadership practice in Kuwait

$\mathrm{S} 1$ believed that culture has a huge influence because people expect they will bond because of their nationality.

"And wasta thing ... it leads to corruption."

S2 was quite forthright when he conceded that,

“Wasta 'kills' you."

On the other hand, social networking is the main ingredient of culture for S3, in which he described that social norms are much more valued than principles and the code of conduct. Another dominant thing for him is wasta:

"Most people respect that because most people believe that without wasta they are of no value".

Conversely, S4 believes that the banking sector is far apart from the national culture. She believes the main artefact of that national culture is certainly wasta. Moreover, S5 claimed that wasta is always present, which she finds only exacerbates the problem of corruption:

"Family names take privileges."

Industrija, Vol.49, No.1, 2021 
How subordinates see the decision process and relationship with leaders

In S1's organization, management is in charge of decisions and relationships with leaders are based on fear. Moreover, he notes that there is no social contact outside the walls of the company:

"Gathering after work, no. More in government (sector)".

For him, people who are working know what is best for the company. In S2's field of work, the managers, LS2, are in charge of decision making. He pointed at the differences in management styles between his ex-manager and the newly appointed manager. He cited that his previous manager knew what is good for the organization, and describes him as someone who wanted to upgrade the working practices of the ministry:

"I liked him like a brother. The new one, very different; he came with wasta. He doesn't care about anything".

In S3's university, managers are solely in charge of decision-making; they have general guidance and they act according to the social norms. He explains that social connections are the key ingredients of the relationship between leaders and subordinates.

"In fact, some subordinates are much stronger than their managers because of the social connections... If you have strong social connections, I will ask you to join the group. I don't want to be harmed from the social connections that you have."

S3 also stated that top management knows what is best for the organization, sometimes even including people outside the organization, like the government. S4 stated that management is in charge of the decisions in her bank. There are no relationships with subordinates outside of work in that bank. According to S4, management knows what is best for the company. S5 claimed that they all know what is best for the company, but managers are in charge of the future of the company. She also described the relationship between leaders and subordinates as strictly professional.

How subordinates see wasta

S1 concurred that wasta leads to corruption. If wasta does not interfere with other people's rights and freedom, he would be fine with it:

"But if it is as the one we have now, it's harming everybody."

S2 agrees in seeing wasta as a big problem in Kuwait. It is a practice in any ministry and without wasta, it is very hard to advance one's career.

"Many people, my friends, and family, we work in ministry (government), but we want to get out of ministry, to another place ... because the wasta kills you."

S3 believes that wasta has a destroying effect:

"You need it everywhere. Many people try to think that wasta is something you must respect."

Concurrently, S4 also believes that wasta is bad, although she said that some people like wasta:

64

Industrija, Vol.49, No.1, 2021 
"This [wasta] is the main thing. In every place. I mean everywhere ... Even in education."

S5 is very direct regarding wasta. She views it as a very bad thing that leads to corruption, and urged that wasta should be removed from Kuwait:

"Maybe you are surprised because I am Kuwaiti, and I am telling you this. I would like that to happen. It's not only on my work level; it's everywhere, in any area."

However, her worry is that removing wasta would not be possible. Nevertheless, she did not portray her manager as wasta influenced but as a professional. 